\title{
Sosyal Öğrenme Bağlamında İllegal Bir Davranış Olarak 'POS Tefecilerde Kart Kırdırma': Bingöl Üniversitesi Öğrencileri Örneği
}

\section{Negotiating Credit Cards In POS Divece Usury As An Illegal Act In The Context Of Social Learning: The Case Of Bingol University Students}

\author{
Mehmet Seyman Önder a,* \\ ${ }^{a}$ Dr. Öğr. Üyesi, Bingöl Üniversitesi, Fen Edebiyat Fakültesi, 12000, Bingöl/Türkiye. \\ ORCID: 0000-0003-4317-1099
}

\section{MAKALE BİLGISİ}

Makale Geçmişi:

Başvuru tarihi: 02 Ocak 2020

Düzeltme tarihi: 12 Nisan 2020

Kabul tarihi: 27 Nisan 2020

Anahtar Kelimeler:

Pos Tefecilik

Kredi Kartı Kırdırma

Sosyal Öğrenme
ÖZ

Ekonomik sorunlara bireylerin getirdiği illegal çözüm yöntemi olarak tefecilik, gelişen teknoloji ve yaygınlaşan bankacılık hizmetleri ile birlikte boyut değiştirmiş, pos tefecilik halini almıştır. Pos tefecilerde kartla para çekme eylemi de 'kart kırdıma' olarak anılmaktadır. Yaygınlaşan bir davranış olan pos tefecilerde kart kırdırma eylemi mağduriyetler de doğurmaktadır. Bu mağdurların önemli bir kısmını da üniversite öğrencileri oluşturmaktadır. Bu çalışmanın evreni Bingöl Üniversitesi öğrencileridir. Örneklem grupları, nicel veri tekniği için tabakalı ve basit seçkisiz tekniklerle belirlenen 460 öğrenciden, nitel veri için ise amaçlı örnekleme tekniğinin kullanılarak seçilen 12 öğrenciden oluşturulmuştur. Kart kırdıran öğrencilerin aile ve arkadaşların borç edinmekten kaçındığı, çoğu öğrencinin kart kırdırma eyleminin suç olduğunu bilmediği, bazılarının ceza alsa bile eylemi tekrar etme eğilimde olduğu görülmüştür. Öğrenciler arasında kart kırdırma eyleminin sosyal öğrenme yoluyla yaygınlaştı̆̆ı anlaşılmıştır.

\section{A B S T R A C T}

As a method of illegal solution brought by individuals to economic problems, usury has turned into the form of POS usury with changing technology and expanding banking services. The majority of victims are university students. The sample groups are composed of 460 students determined by stratified and simple random techniques for quantitative data technique, and 12 students who were selected for qualitative data by using purposive sampling technique. In the study, It was detected that students who negotiated cards refuse to borrow money from their families and friends, and that most students do not know that the act of negotiating cards was a crime. The negotiating card among students is becoming widespread with social learning.

POS Device Usury,

Negotiating Credit Card

Social Learning Theory

\section{Giriş}

İnsanlar yaşamları boyunca çeşitli sorunlarla karşılaşmakta, bu sorunlara doğal olarak da bir çözüm getirmeye çalışmaktadır. Ancak bazen çözüm yöntemleri alışılagelmişin dışında olabilmektedir. En sık karşılaşılan sorunlardan biri ekonomik yetersizliklerdir. Sorunların çözümü için legal çözümler getirildiği gibi bazen de illegal çözümler getirilmektedir. Gerek sosyal hayatta gerekse de ticari hayatta bu soruna getirilen başlıca illegal çözüm, yüksek faizli kayıt dışı para alış verişidir. Türk Ceza Kanunu 241. Maddesine (2004) göre bu alış veriş "tefecilik" olarak nitelendirilmiş ve cezai müeyyideye tabi tutulmuştur. Kanuna göre tefecilik "kazanç elde etmek amaciyla ödünç para verilmesi" olarak tanımlanmıştır. Tefecilik ve tefeciliğin tanımına, çeşitlerine, getirilen cezai yaptırımlara ve kanunlardaki yerine yönelik çeşitli bilimsel araştırmalar yapılmış (Arslan, 2014; Bahar, tarih yok; Bekar, 2013; Bilge, 2015; Cenikli, 2017; Gönenç, 2010; Gün, 2019) ve tefecilik, hukuki anlamda detaylı bir şekilde tartışılmıştır. Ancak, teknolojinin gelişmesiyle birlikte tefecilik türünde ve yöntemlerinde de çeşitli değişiklikler yaşanmıştır. İnternet ve iletişim ağının güçlenmesi ile hemen her iş yerinde pos cihazlarının bulunması mümkün

\footnotetext{
* Sorumlu yazar/Corresponding author.

e-posta: msonder@bingol.edu.tr
} 
hale gelmiştir. Bu cihazların çoğalması ve kontrolünün zorlaşması; art niyetle, amaç dişı kullanımına imkân tanımıştır. Bankaların istediği şartların sağlanamaması ya da düşük miktarlı acil ihtiyaçlar için bankların prosedürleri ile zaman kaybedilmek istenmemesi nedeniyle tüketici kredisi almayan/alamayan ve kredi kartına sahip olan bireyler, çeşitli iş yerlerinden alış veriş yapmış gibi gösterilerek kredi kartlarından nakit çekmektedirler. Kişiler, bir kuyumcu, bir teknoloji mağazası ya da bir beyaz eşya mağazasına gitmekte, altın ya da beyaz eşya satın alınmış gibi pos cihazından, kart sahiplerinin kartlarından taksitli şekilde para çekilmektedir. Kart sahibinin ihtiyaç duyduğu paray1; iş yeri sahibi, komisyonunu ya da faizini de ekleyerek çekmektedir. Örneğin kart sahibi 1000 TL'ye ihtiyaç duyuyorsa ve iş yeri sahibi komisyon bedelini 100 TL olarak belirlenmişse karttan 1.100 TL çekilmekte, kart sahibine $1.000 \mathrm{TL}$ verilmektedir. Komisyon miktarı ise çekilen iş yerine, paranın miktarına ve kaç taksit yapıldığında göre yüzde 3 ile yüzde 20 arasında değişmektedir. $\mathrm{Bu}$ durum, Türkiye'de yaygınlık kazanmaktadır. Bu konu zaman zaman basın yayın organlarında haber olarak da gündeme gelmektedir. Ancak, Arslan (2014), Gün (2019) ve Karakehya (2013) vb. araştırmacıların yaptığı ve daha çok tefeciliğin hukuki boyutunun ele alındığı bilimsel araştırmalar da mevcuttur. $\mathrm{Bu}$ araştırmaların hemen hepsinde bu tefecilik türü için "pos tefecilik" terimi kullanılmıştır.

Daha önce yapılmış ve hukuki boyutunun ele alındığı çalışmalardan farklı olarak bu araştırmanın önemi; bu suç fiilinin sosyolojik boyutta ele alınmış olmasıdır. Bu fiilin yarattığı mağdurların sayısının ciddi miktarlara ulaştığı ve de bu mağduriyetin özellikle de üniversite öğrencileri arasında gittikçe artarak yaygınlaştığı yönünde bazı belirtileri tespit etmiş olmasıdır. Hatta bu durumu kazanç kapısına dönüştüren bazı kişiler, kuyumcu adı altında tefeci büroları açmakta, mağdurlar üzerinden ciddi kazançlar sağlamaktadır. Öğrencilerin böyle bir yola tevessül etmesine yol açan en önemli etmen ise, öğrencilere burs ve öğrenim kredisi için bankalar tarafindan verilen kartlara; nakit avans kredisi ile alışveriş kredilerinin yüklenmiş olmasıdır. Burs veya öğrenim kredisi ücretlerini tüketen öğrenciler, yeni ihtiyaçları için banka tarafindan verilen nakit avans kredilerini tüketince, kartlarına tanımlanmış olan alışveriş kredisini de nakit olarak çekebilmek için pos tefecilere başvurmaktadırlar. Bu işlem, öğrenciler arasında "kart kırdırma" olarak isimlendirilmektedir. Bu çalışmada Bingöl Üniversitesi örneğinde öğrencilerinin kart kırdırma alışkanlıkları ve bu alışkanlığı doğuran etkenler incelenmektedir. Bu konuda Türkiye'de yapılmış benzer bir çalışmaya rastlanılmamıştır. Yapılan çalışmalar daha çok kredi kartı kullanım alışkanlıkları üzerinedir. Örneğin, Durukan vd. (2005) kredi kartlarındaki taksit uygulamasının tüketicinin harcama alışkanlıkları üzerindeki etkisini araştırmışlardır. Bülent vd. ise (2012) Kredi kartını kullanımı etkileyen faktörler üzerinde yoğunlaşmışlardır. Ancak konusu itibariyle araştırmamıza en yakın olan çalışma Girginer vd. (2008) tarafından Eskisehir Osmangazi Üniversitesi İktisadi ve İdari Bilimler Fakültesi ögrencilerinin kredi kartı kullanım alışkanlıklarına yönelik olarak yapmışlardır. Uluslararası literatürde de öğrencilerin kredi kartı kullanma alışkanlıklarına yönelik bazı çalışmalara rastlanmıştır. Amerika'da Hayhoe vd. (1999), Warwick ve Mansfield (2000), Xiao vd. (1995) öğrencilerin kredi kartı kullanımları üzerine çalışmalar yapmışlardır.
Yine Amerika'da Littwin (2007) düşük gelirlilerin kredi kartı kullanım alışkanlıkları üzerine çalışmıştır. Almanya'da ise Achtziger vd. (2015) kredi kartı ile kontrolsüz alışveriş ve borçlanma üzerine araştırma yapmışlardır.

$\mathrm{Bu}$ araştırmada ise illegal bir davranış olarak öğrencilerin, bir kredi kartı niteliği taşıyan burs ile öğrenim kredisi kartlarını kırdırma durumları, bu davranışın ortaya çıkma nedenleri ve yaygınlaşması üzerinde durulacaktır. $\mathrm{Bu}$ davranışın ortaya çıkmasını sağlayan koşullar kadar yaygınlaşmasında etken olan unsurların da tartışılmasına ihtiyaç vardır. Kart kırdırma yasalarda tefecilik olarak tanımlanan suç kapsamına girmektedir. Suçun varlığına ve yaygınlaşmasına yönelik birçok teori mevcuttur. Ancak öğrencilerin kart kırdırma davranışları, bu çalışmada öğrenme kuramları ile ele alınacaktır. Öğrenme yaklaşımlarının temeli Edwin Sutherland'ın "Ayırıcı Birliktelik" teorisine, Sutherland'ın teorisi ise Gabriel Tarde'nin Suçun Taklidi teorisine dayanmaktadır.

Tarde 1903 yılında yayınladığı The Laws of Imitation adlı eserinde hayatın her alanında taklitlerin olduğunu ifade etmektedir. Tüm sosyal davranışların taklit edildiğini belirten Tarde, toplumsal normlara uyan davranışlar gibi, normlara aykırı davranışların da taklit edildiğine vurgu yapmaktakdır. Ancak Tarde, taklit kuramını sadece suç davranışını açıklamak için değil, tüm sosyal davranışları açıklamak için oluşturmuştur. Sutherland (1947) ise Principle of Criminology adlı genişletilmiş dördüncü baskı olan eserinde Tarde'nin taklid kuramını Differential Association Theory ile yani 'Ayırıcı Birliktelik Teorisi'yle daha sistematik hale getirmiştir. Sutherland, bu teoriyi üç düzlemde ele almaktadır. Birincisi normatif çatışma, ikincisi ayrıcı birliktelik ve sonuncusu ise ayricı grup organizasyonudur (Burgess \& Akers, 1966; Metsueda, 2010).

Toplumsal düzeyde, suç normatif çatışmaya dayanır. Sutherland'a göre, ilkel, farklılaşmamış toplumlar, temel değerler ve inançlar üzerindeki uyum, dayanışma ve fikir birliği ile karakterize edilir. Bu tür toplumlar uygun davranışlar konusunda çok az çatışmaya sahiptir ve sonuç olarak da suç oranı düşüktür. Sanayi devrimi ile birlikte toplumlar, emek, ekonomik değerler konusunda derin ayrışmalar yaşamıştır. $\mathrm{Bu}$ tür topluluklar, toplumsal değerler ve davranış kalıplarına aykırı düşen davranışlar geliştirirler. Bunlar, benzerlikten ziyade uzmanlaşma, uyumdan ziyade zorlama, konsensüsten ziyade çatışma ile karakterizedir. Yüksek suç oranlarına sahip olma eğilimindedirler. Ayırıcı birliktelik, bireysel düzeyde toplumdaki normatif çatışmanın bireysel eylemlere nasıl dönüştüğü hakkında sosyo-psikolojik açıklama sağlar. Buna göre suçlu davranış, samimi gruplar arasında yaşanan iletişim ile öğrenilir (Burgess \& Akers, 1966; Metsueda, 2010).

C. R. Jeffery, Robert L. Burgess ve Ronald L. Akers, Tarde'nin ve Suhterland'ın teorileri üzerinde yoğunlaşmış, Jeffery 1965 'te "Criminal Behavior and Learning Theory" adlı eseri, Burgess ve Akers ise 1966'da "A Differential Association-Reinforcement Theory of Criminal Behavior" adlı çalışmayı yayınlamışlardır. Daha sonra ise Akers bu çalışmalardan yola çıkarak Sosyal Öğrenme Yaklaşımını geliştirerek 1973 yayınladığı Deviant Behavior: A Social Learnig Approach adlı eseri yayınlamıştır. 
Jeffery (1965), bireylerin istenilen davranışı ya da istenilmeyen davranışının gerçekleştirilmesinin olumlu ve olumsuz pekiştireç ile birlikte olumsuz ve olumlu cezalarla sağlanabileceğini belirtmiş; pekiştireçler, cezalar ve davranışlar arasındaki ilişkiyi bir tablo ile izah etmiştir.

Tablo 1: Jeffery’nin Uyarıcılar ve Davranışlar Arasındaki İlişki Tablosu

\begin{tabular}{lll}
\hline & Davranış artışı & $\begin{array}{l}\text { Davranış } \\
\text { azalması }\end{array}$ \\
\hline Sunulan uyarıcı & Olumlu pekiştireç & Olumlu ceza \\
\hline $\begin{array}{l}\text { Ortadan kaldırılan } \\
\text { uyarıcı }\end{array}$ & Olumsuz pekiştireç & Olumsuz ceza \\
\hline
\end{tabular}

Tablodaki uyarıcılar ve etkileri örneklerle şu şekilde açıklanabilir. Bir çocuğu ders çalışmaya motive etmek için bisiklet alınması olumlu pekiştireçtir. Dersinde başarılı olan çocuğun yaz tatilini bakkalın yanında çırak olarak geçirmeyecek olması durumunda bakkal çıraklığı olumsuz pekiştireçtir. Çocukta azalması beklenilen davranış yaramazlık yapmamasıdır. Çocuğun azarlanması olumlu ceza, çocuğa parka/sokağa çıkmama cezası verilmesi olumuz cezadır. İstenilmeyen davranışı gerçekleştiren bireylerin cezalardan mahrum kalması ya da istenilen davranışı sergilemeyen bireylerin pekiştireçlerden mahrum kalması durumunda beklentinin aksine bir davranış geliştiği ifade edilmektedir. İstenilmeyen yani suç davranışını gerçekleştiren bireyin ödüle (doğrudan ya da dolaylı olarak) maruz kalması durumunda suç davranışı pekiştirilerek öğrenilmektedir. Jeffery'nin ve Akers'in kuramları birbirine çok benzemekle birlikte bir birini tamamlayan bir nitelik taşımaktadır.

Akers, sosyal davranışın, hem doğrudan koşullandırma hem de başkalarının davranışlarının taklit edilmesi veya modellenmesi yoluyla kazanılabileceğini söylemektedir. Davranış, olumlu pekiştireç olarak ödülle ve olumsuz pekiştireç olarak cezadan kaçınmanın önlenmesi ile pekiştirildiği gibi önleyici uyanlar olan cezalar veya ödül kaybı ile de zayıflatılabilir. Sapkın ya da uygun davranışın elde edilip edilmemesi ya da devam etmesi, davranış için geçmiş ve şimdiki ödüllere ya da cezalara bağlıdır. Ayrıca insanlar, yaşamlarında önemli gruplarla etkileşime girerek davranışlarının iyi veya kötü olduğunu öğrenirler. İnsanların davranışlarını, sosyal pekiştireçler kadar, sosyal olmayan (uyuşturucu maddelerin dolaylı psikolojik etkileri vb.) pekiştireçler de belirleyebilir (Akers vd., 1979).

Üniversite öğrencileri arasında yaygınlaşan pos tefecilerde kart kırdırma davranışı, azalması arzu edilen sapkın davranış olmakla birlikte bu davranışı ortaya çıkaran ve artıran pekiştireçler üzerinde durulması gerekmektedir.

$\mathrm{Bu}$ araştırma, öğrenciler arasında bir sorun çözme yöntemi olarak geliştirilen bir illegal davranışın açığa çıkarılmasını hedeflemektedir. Öğrencilerin aldı ̆̆ 1 burs ve öğrenim kredilerinin miktarının artması ile birlikte bankalar, öğrencileri potansiyel kredi kartı kullanıcısı olarak görmüşler ve öğrencilerin banka kartlarına kredi bakiyeleri yüklemişlerdir. Banka kartlarına yüklenen bakiyeler ise bazı öğrenciler tarafından suiistimal edilmiştir. Öğrencilerin banka kartlarını suiistimaline yönelik davranışları, bu çalışma ile birlikte bilimsel anlamda ilk kez incelenmiştir.

$\mathrm{Bu}$ çalışmanın; öğrenciler arasında sosyal öğrenme yöntemiyle gittikçe yaygınlaşan bu davranışın önlenmesi ve öğrencilerin sorunlarına daha rasyonel çözümler getirilmesi hususunda politika yapıcılara ve ayrica bu konuda yapılacak yeni araştırmalara yol gösterici olması amaçlanmaktadır.

\section{Araştırmanın Yöntemi}

\subsection{Araştırma Modeli}

Araştırmada "İlişkisel Tarama Modeli” kullanılmıştır. İlişkisel tarama modeli, iki ve daha çok sayıdaki değişken arasında birlikte değişimin varlığını ve/veya derecesini belirlemeyi amaçlamaktadır (Karasar, 2017: 114). Bir sapma davranışı olan pos tefecilerde kart kırdırma davranışı bu davranışı etkileyen değişkenlerin durumları ile değişkenler arasındaki ilişkiler incelenmiştir.

\subsection{Araştırmanın Evreni ve Örneklemi}

Araştırmanın evrenini Bingöl Üniversitesi öğrencileri oluşturmaktadır. Nicel verilerin toplandığı örneklem grubunda 460 öğrenci yer almıştır. Enformel görüşmeler için de 12 öğrenciden oluşan örneklem grubu oluşturulmuştur. Anketin uygulandığı örneklem grubu, tabakalı ve basit seçkisiz örnekleme teknikleri kullanılarak belirlenmiştir. Öğrenciler, önce fakültelere, sonra bölümlere ve sonra da sınıflara göre tabakalandırılmış; sonra da tabakalar içerisinde rastlantısal olarak seçilmişlerdir. Enformel görüşme yapılan bireyler ise amaçlı örnekleme tekniği kullanılarak "kart kırdırma" işlemini gerçekleştirmiş en deneyimli öğrenciler arasından seçilmiştir

\subsection{Veri Toplama Teknikleri}

Veri toplamak amacıyla iki ayrı veri aracı kullanılmıştır. Nicel veri elde edilebilmesi amacıyla 36 sorudan oluşan anket formu ve nitel veri toplanabilmesi amacıyla da 22 sorudan oluşan yarı yapılandırılmış enformel görüşme formu uygulanmıştır.

\subsection{Verilerin Analizleri}

Anket formu ile elde edilen veriler SPSS programı ile analiz edilmiştir. Anket formu kategorik sorulardan oluştuğu için veriler, nanparametrik testlerden Ki-Kare ve Fisher'in Tam Olasılık (Exact Test) testlerine tabi tutulmuştur. $\mathrm{Bu}$ testlerin yapılmasının amacı genel olarak cevaplar arasında anlamlı farklılaşmaların olup olmadığını tespit etmektir (Büyüköztürk, 2011: 146-148; Can, 2017:335-347). Bu çalışmada da, bahsedilen testler uygulanarak nitel ve nicel bulguların betimsel analizleri yapilmıştır.

\subsection{Araştırmanın Hipotezleri}

Hipotez 1: Öğrencilerin burs ya da öğrenim kredisi alıyor olması ile kart kırdırmaları arasında pozitif bir ilişki vardır.

Hipotez 2: Öğrencilerin eğlence mekânlarına gitme durumları ile kart kırdırma arasında pozitif bir ilişki vardır.

Hipotez 3: Öğrencilerin çalışıyor olmaları ile kart kırdırmaları arasında negatif bir ilişki vardır.

Hipotez 4: Öğrencilerin ailelerinden maddi destek alma durumları ile kart kırdırmaları arasında negatif bir ilişki vardir. 
Hipotez 5: Öğrenciler, nakit ihtiyaçlarını karşılamak için aile ve arkadaşlarından borç istemekten kaçınmaktadırlar

Hipotez 6: Öğrenciler, nakit ihtiyaçlarını karşılamak için ilk olarak bankaların sunduğu imkânları kullanmayı tercih etmektedirler

Hipotez 7: Kart kırdırmanın suç olduğunu bilme durumu, öğrencilerin eylemi gerçekleştirmelerinde belirleyici unsur değildir.

Hipotez 8: Kart kırdırma eyleminin yaygınlaşmasının yollarından biri sosyal öğrenmedir.

\section{Bulgular}

Araştırma kapsamında öğrencilerin kart kırdırma durumları tespit edilmiş ve kart kırdırma durumları ile çeşitli değişkenler arasında bir ilişkinin olup olmadığı anlaşılmaya çalışılmıştır. Bu kapsamda elde edilen nitel ve nicel bulgulara bu bölümde yer verilerek yorumlanmıştır. Nitel veriler 12 ayrı görüşmeciden elde edilmiş olmakla beraber, veri tekrarı oluşmaması için tüm katılımcıların görüşme notlarına değil, geneli temsil eden ya da çarpıcı olduğu kanaati getirilen nitel görüşme verilerine yer verilmiştir.

Tablo 1: Katılımcılara Ait Bazı Demografik Veriler

\begin{tabular}{|c|c|c|}
\hline Cinsiyet & $\mathbf{F}$ & $\%$ \\
\hline Erkek & 198 & 43,0 \\
\hline Kadın & 262 & 57,0 \\
\hline Toplam & 460 & 100,0 \\
\hline \multicolumn{3}{|l|}{ Kardeş sayısı } \\
\hline 1 kardeş & 27 & 5,9 \\
\hline 2 kardeş & 42 & 9,1 \\
\hline 3 kardeş & 68 & 14,8 \\
\hline 4 kardeş & 64 & 13,9 \\
\hline 5 kardeş & 61 & 13,3 \\
\hline 6 kardeş ve fazlası & 198 & 43,0 \\
\hline Toplam & 460 & 100,0 \\
\hline \multicolumn{3}{|l|}{ Ailenin aylık geliri } \\
\hline Geliri yok & 66 & 14,3 \\
\hline Asgari ücret ve altı & 229 & 49,8 \\
\hline $2100-3500$ & 115 & 25,0 \\
\hline $3501-5000$ & 40 & 8,7 \\
\hline 5001 ve üstü & 10 & 2,2 \\
\hline Toplam & 460 & 100,0 \\
\hline \multicolumn{3}{|c|}{ Burs ve kredi alma durumu } \\
\hline Burs alıyorum & 213 & 46,3 \\
\hline Öğrenim kredisi alıyorum & 183 & 39,8 \\
\hline Her ikisini de alıyorum & 3 & ,7 \\
\hline Hiç birini alıyorum & 61 & 13,3 \\
\hline Toplam & 460 & 100,0 \\
\hline \multicolumn{3}{|l|}{ Çalıșma durumu } \\
\hline Çalışmıyorum & 437 & 95,0 \\
\hline Yarı zaman çalışıyorum & 17 & 3,7 \\
\hline Tam zamanlı çalışıyorum & 6 & 1,3 \\
\hline Toplam & 460 & 100,0 \\
\hline \multicolumn{3}{|l|}{ Kişisel aylık geliri } \\
\hline 500 ve alt1 & 244 & 53,0 \\
\hline $501-650$ & 95 & 20,7 \\
\hline $651-800$ & 56 & 12,2 \\
\hline $801-950$ & 29 & 6,3 \\
\hline $951+$ & 36 & 7,8 \\
\hline Toplam & 460 & 100,0 \\
\hline \multicolumn{3}{|l|}{ En büyük gider kalemi } \\
\hline Beslenme & 127 & 27,6 \\
\hline Giyim & 52 & 11,3 \\
\hline Yurt-konut kirası & 201 & 43,7 \\
\hline Kitap ve kırtasiye gideri & 55 & 12,0 \\
\hline Eğlence & 25 & 5,4 \\
\hline Toplam & 460 & 100,0 \\
\hline
\end{tabular}

Araştırma hedef kitlesi içinde yer alan öğrencilerin \% 43'ü erkek \% 57'si ise kadınlardan oluşmakta, katılımcıların \% 46,3 sadece burs, \% 39,8'i ise sadece öğrenim kredisi almaktadır. Öğrencilerin \% 53’ü 500 TL ve altında bir gelire sahiptir.

Tablo 2: Öğrencilerin Kart Kırdırma Durumları İle Burs Veya Öğrenim Kredisi Alma Durumları Arasındaki İlişki -Ki Kare Testi Sonuçları

\begin{tabular}{|c|c|c|c|c|}
\hline \multirow[b]{2}{*}{$\begin{array}{l}\text { Kart kırdırn } \\
\text { durumu }\end{array}$} & \multicolumn{3}{|c|}{$\begin{array}{c}\text { Burs veya öğrenim kredisi alma } \\
\text { durumları }\end{array}$} & \multirow[b]{2}{*}{ Toplam } \\
\hline & Burs aliyorum & $\begin{array}{c}\text { Öğrenim } \\
\text { kredisi } \\
\text { alıyorum }\end{array}$ & $\begin{array}{l}\text { Hiç birini } \\
\text { alıyorum }\end{array}$ & \\
\hline \multirow{2}{*}{ Kart kırdırdım $\begin{array}{l}\mathrm{F} \\
\%\end{array}$} & 63 & 59 & 8 & 130 \\
\hline & 29,6 & 32,2 & 13,1 & 28,4 \\
\hline \multirow{2}{*}{$\begin{array}{l}\text { Hiç kart } \\
\text { kırdırmadım }\end{array}$} & 150 & 124 & 53 & 327 \\
\hline & 70,4 & 67,8 & 86,9 & 71,6 \\
\hline \multirow{2}{*}{ Toplam } & 213 & 183 & 61 & 457 \\
\hline & 100.0 & 100,0 & 100,0 & 100,0 \\
\hline Chi-Square Tests & Value & df & \multicolumn{2}{|c|}{ Asy. Sig, (2-sided) } \\
\hline $\begin{array}{l}\text { Pearson Chi- } \\
\text { Square }\end{array}$ & $8,473^{\mathrm{a}}$ & 2 & & \\
\hline
\end{tabular}

Öğrencilerin kart kırdırma durumlarının burs veya öğrenim kredisi alma durumlarına göre farklılık gösterip göstermediğini ya da burs veya öğrenim kredisi almalarıyla ilişkili olup olmadığına ilişkin Ki-kare testi sonuçlarına Tablo 2'de yer verilmiştir. Tablo incelendiğinde burs alanların yüzde 29,6'sı, öğrenim kredisi alanların ise \% 32,2'si kart kırdırdığını ifade etmiştir. Burs veya kredi almadığını beyan edenlerin ise sadece \% 13,3 kart kırdığını gözlemlenmiştir. Burs veya öğrenim kredisi alanlarda kart kırdırma oranın arttığı, herhangi birini almayanlar da ise oranın düştüğü ve gözlenen bu farkın anlamlı olduğu tespit edilmiştir. $\mathrm{X}^{2}(\mathrm{df}=2, \mathrm{n}=457)=8,47 ; \mathrm{P}<.05$

Hipotez 1: doğrulanmıştır.

Tablo 3: Öğrencilerin Kart Kırdırma Durumu İle Kafe ve Benzeri Eğlence Mekânlarına Gitme Durumları Arasındaki İliş̧i-Ki Kare Testi Sonuçları

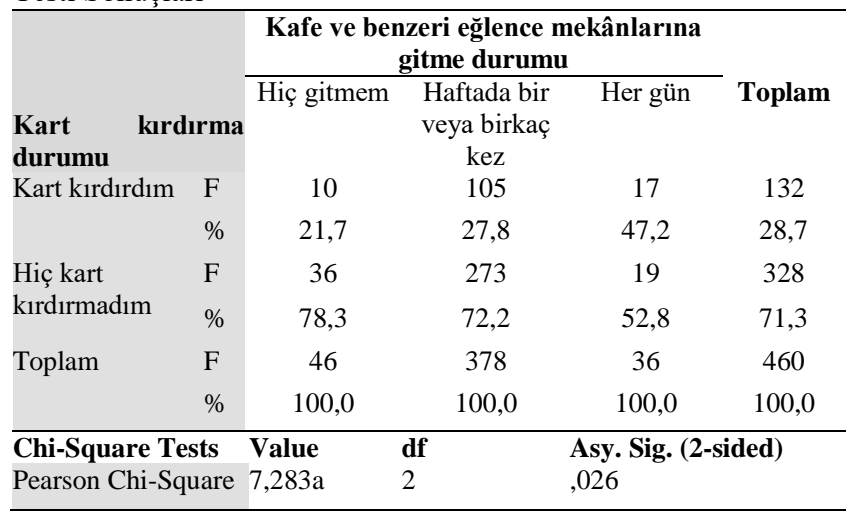

Bazı öğrenciler, gelirlerinin bir miktarını kafe ve eğlence mekânlarına sik sik giderek tüketmektedir. Öğrenciler genellikle bu mekânlarda nakit para kullanmaktadır. Nakit para ihtiyaçlarının kart kırdırılarak karşılandığı dikkate alınarak öğrencilerin eğlence mekânlarına gitme durumları ile kart kırdırma değişkenleri bir ilişki olduğu öngörülmüştür. İki değişken arasındaki ilişkiyi gösteren Ki-kare testi sonuçlarına Tablo 3 'te yer verilmiştir. Tabloya bakıldığında kafe ve benzeri eğlence mekânlarına hiç gitmeyenlerde kart kırdırma oranı \% 21,7 iken, haftada bir veya birkaç kez gidenlerde \% 27,8; her gün gidenlerde ise bu oranın \% 47,2 olduğu görülmektedir. Ki-kare testi sonuçlarına göre eğlence mekânlarına gitme oranı arttıkça kart kırdırma oranında arttığı gözlendiğinden bu iki değişken arasındaki anlamlı bir ilişki olduğu bulunmuştur. 


$$
\mathrm{X}^{2}(\mathrm{df}=2, \mathrm{n}=460)=7,28 ; \mathrm{P}<.05
$$

Hipotez 2: doğrulanmıştır.

Öğrencilerin eğlence mekânlarına ve boş zamanlarını değerlendirme alışkanlıklarına yönelik nitel görüşme notları aşağıdaki gibidir.

G2: "Öğrenci evinde kaldığımız için genelde bir yemek problemimiz oluyor. Bu yüzden sık sık dışardan yemek yeme durumda kalıyoruz. Hafta bir 3-4 kez dişarıda yemek yiyoruz. Yemekle beraber giyim, sigara da oluyor. Bazen de şans oyunlarında da şansımızı deniyoruz. Öğrenciler arasında İddia, futbol, basketbol filan çok yaygındır."

G6: "Birinci sinıftayken ilk kez ailemden uzak olduğum, özgür olduğum bir imkân bulmuştum. Arkadaş ortamındaydım. Sürekli harcıyordum. Önce bursları harcadım. Sonra nakit avansı çektim kullandım. Sonra da kredi kartlarını kullanmaya başladım. Paraları arkadaş ortamında yedim gitti. Sonra bir daha da borçları kapatamadım."

Boş zamanlarını değerlendirmeye yönelik alışkanlıklar arasında ön plana çıkan kafe, kıraathane ve çay bahçesi gibi yerlerde zaman harcamak öğrencilerin büyük bir bölümünde görülen bir alışkanlıktır. Bununla beraber şans oyunları merkezlerine giden öğrenciler de mevcuttur. Öğrencilerin gittikleri yerlerin bu tür mekânlarla sinırlı olmasının nedeni de Bingöl ilinin küçük ve sosyal aktivite imkânlarının oldukça sınırlı olmasıdır.

Kart kırdırma ile öğrencilerin çalışma durumları arasında ve kart kırdırma ile aileden maddi destek alma durumları arasındaki ilişkilerde Ki-kare testine tabi tutulmuştur. Test sonuçları aşağıdaki gibidir.

Tablo 4:Kart Kırdırma İle Öğrencinin Çalışma Durumu Arasındaki İlişkiyi Gösteren Ki-Kare Testi Sonucu

\begin{tabular}{llll}
\hline Chi-Square Tests & Value & df & Asy. Sig. (2-sided) \\
\hline Pearson Chi-Square & $1,822^{\mathrm{a}}$ & 2 &, 402 \\
\hline
\end{tabular}

Öğrencilerin bir işte çalışma durumlarının kart kırdırmaları arasında bir ilişki olup olmadığına ilişkin $\mathrm{Ki}$-kare testi sonuçlarına bakıldığında $\mathrm{X}^{2}(\mathrm{df}=2, \mathrm{n}=460)=1,82 ; \mathrm{P}>.05$ olduğu, iki değişken arasında anlamlı bir ilişki olmadığ anlaşılmaktadır.

Hipotez 3: yanlışlanmıştır

Tablo 5: Kart Kırdırma Durumu İle Aileden Maddi Destek Alma Arasındaki İlişkiyi Gösteren Ki-Kare Testi Sonucu

\begin{tabular}{llll}
\hline Chi-Square Tests & Value & df & Asy. Sig. (2-sided) \\
\hline Pearson Chi-Square & $3,290^{\mathrm{a}}$ & 2 &, 193 \\
\hline
\end{tabular}

Katılımcıların ailelerinden maddi destek alma durumları ile kart kırdırmaları arasında bir ilişski olup olmadığına ilişkin Ki-kare testi sonuçlarına bakıldığında $\mathrm{X}^{2} \quad(\mathrm{df}=2$, $\mathrm{n}=460)=1,93 ; \mathrm{P}>.05$ olduğu, iki değiş̧en arasında anlamlı bir ilişkinin bulunmadığı anlaşılmaktadır.

Hipotez 4: yanlışlanmıştır.

Öğrenim kredisi ve bursları öğrencilerin ihtiyacına yeterli gelmediği için öğrencilerin hemen hepsine yakını, ailelerinden kısmi olarak maddi destek almaktadır. Ancak bazı ailelerinden gelen destek yetersiz olmakla birlikte öğrenci, ailesinden destek isteme konusunda isteksiz davranmaktadır. İsteksizliklerini belirttikleri nitel görüşme verilerine aşağıda yer verilmiştir.

G1: "Ailemin haberi yok böyle bir şey istemezler ben ailemden para istemek istemediğim için bu yöntemi denedim. Bir başkasından para borç etmek istemiyorum. Bir başka kişiden para istemek beni rahatsız ediyor. Sırf 6 lira fazla vermemek için neden bir başkasından isteyeyim ki. Kimseye borçlanmak istemem. Bankaya borçlarım en azından kimsenin nazını çekmem."

G4: "Ben gururlu bir insanım başkasından gidip para isteyemem. Başkasından isteyeceğime bankadan borç edinirim daha iyi. Komisyon ödeyip zarar ederim de kimsenin mihnetini çekemem."

G6: "Kimseye gidip borç edip ağız eğemem. Babamdan dahi gidip istemiyorum."

Ailelerinden minimal düzeyde de olsa destek alan öğrenciler, bir ay içinde ikinci kez paraya ihtiyaç duyduğunda zaruri giderler dışında geçerli bir nedeni yoksa ailelerinden maddi destek istememektedirler. Bunun iki nedeni vardır. Birincisi ailelerinin sosyo-ekonomik anlamda yaşadıkları yetersizlikler yüzünden belli bir miktarın üzerinde destek sağlayamayacaklarını bilmeleri, ikinci neden ise ailelerinin 'bu kadar parayı ne yapiyorsun' şeklinde bir tepki göstermelidir.

Tablo 6: Öğrencilerin Kart Kırdırma Durumları İle Nakit İhtiyaçlarını Karşılamak İçin İlk Başvurdukları Yöntem Arasındaki İlişkiyi Gösteren Kİ-Kare Testi Sonucu

\begin{tabular}{|c|c|c|c|c|c|c|c|}
\hline \multirow[b]{2}{*}{$\begin{array}{l}\text { Kart } \\
\text { kırdırma } \\
\text { durumu } \\
\end{array}$} & \multicolumn{3}{|c|}{$\begin{array}{l}\text { Nakit ihtiyacını } \\
\text { başvurduğu yöntem }\end{array}$} & \multicolumn{2}{|c|}{ karşılamak için } & ilk & \multirow[b]{2}{*}{ Toplam } \\
\hline & & $\begin{array}{c}\text { Karttan } \\
\text { nakit } \\
\text { avans } \\
\text { çekme }\end{array}$ & $\begin{array}{c}\text { Kart } \\
\text { kirdirma }\end{array}$ & $\begin{array}{c}\text { Akraba ve } \\
\text { arkadaşlardan } \\
\text { isteme }\end{array}$ & $\begin{array}{l}\text { Günlük } \\
\text { çalışarak }\end{array}$ & Diğer & \\
\hline Kart & $\mathrm{F}$ & 54 & 56 & 4 & 1 & 8 & 123 \\
\hline kırdırdım & $\%$ & 43,9 & 45,5 & 3,3 & 0,8 & 6,5 & 100,0 \\
\hline \multirow{2}{*}{\multicolumn{2}{|c|}{$\begin{array}{l}\text { Hiç kartF } \\
\text { kırdırmadı } \% \\
\text { m }\end{array}$}} & 176 & 0 & 25 & 3 & 34 & 238 \\
\hline & & 73,9 & 0,0 & 10,5 & 1,3 & 14,3 & 100,0 \\
\hline Toplam & $\mathrm{F}$ & 230 & 56 & 29 & 4 & 42 & 361 \\
\hline & $\%$ & 63,7 & 15,5 & 8,0 & 1,1 & 11,6 & 100,0 \\
\hline \multicolumn{3}{|c|}{ Chi-Square Tests } & Value & df & \multicolumn{3}{|c|}{ Asy. Sig. (2-sided) } \\
\hline \multicolumn{3}{|c|}{ Pearson Chi-Square } & $129,525^{\mathrm{a}}$ & 4 &, 000 & & \\
\hline
\end{tabular}

Öğrencilerin kart kırdırma durumları ile nakit ihtiyaçlarını karşılamak için ilk başvurdukları yöntem arasında bir ilişsi olup olmadığına ilişsin Ki-kare testi sonuçları Tablo 6'da gösterilmiştir. Tablo 6'ya bakıldığında kart kırdıran öğrenciler arasında nakit ihtiyaçlarını karşılamak için ilk olarak gündelik işlerde çalışarak kazanmayı tercih edenlerin oranı \% 0,8; akraba ve arkadaşlarından istemeyi tercih edenlerin oranı ise sadece $\% 3,3^{\prime}$ 'tür. Nakit ihtiyaçlarını karşılamak için ilk başvurdukları yöntem olarak kart kırdırdığını söyleyenlerin oranı $\% 45,5$ iken, nakit avans çektiklerini ifade edenlerin oranı \% 43,9 olmuştur. İlk olarak kart kırdığını ifade edenlerin, nakit avans çekmeyi tercih etmemeleri bir çelişki gibi gelmektedir. Ancak bu kişiler düzenli olarak kart kırdırmaktadırlar. İlk olarak nakit avanslarını çekmekte, sonrasında kart kırdırmaktadırlar. Ancak bir sonraki ay yatan burs veya öğrenim kredisi ile sadece kartın kredi borcu ödenebilmekte, nakit avans borcu tekrar devam etmekte, borcu ödenmediği müddetçe nakit avans çekme imkânına sahip olamamaktadırlar. Ancak ilginç olan sonuç hiç kart kırdırmadığını ifade eden ögrencilerin \% 73'nün ilk olarak nakit avans çektiklerini 
ifade etmeleridir. Kart kırdırmayan öğrenciler dahi aile ve arkadaşlarından para istemeyi tercih etmek yerine faiz ödeme pahasına bankaların sundukları imkânları kullanmayı yeğlemektedirler.

Öğrencilerin nakde ihtiyaç duymaları halinde ihtiyaçlarını karşılamak için ilk başvurdukları yöntem ile kart kırdırma değişkenleri arasında Ki-kare testi sonucuna göre anlamlı bir ilişki olduğu gözlenmiştir.

$\mathrm{X}^{2}(\mathrm{df}=4, \mathrm{n}=361)=129,5 ; \mathrm{P}<.05$

\section{Hipotez 5: doğrulanmıştır}

\section{Hipotez 6: doğrulanmıştır}

Tablo 7'de bazı öğrenciler ise “diğer” cevabını vermiştir. Diğer cevabını veren öğrencilerin nasıl bir yöntem kullandıkları sorgulanmış, kullandıkları bazı nakit bulma yöntemlerine ilişkin nitel görüşme verileri elde edilmiştir. Bunlara aşağıda yer verilmiştir.

G1: “...gibi büyük alıș veriş sitelerinden kredi kartıyla alış veriş yapıyorum. İşlemi bitirdikten birkaç dakika sonra işlemi iptal ediyorum. İptal edince alış veriş sitesi kartımdan kestiği parayı nakit olarak normal hesabıma yatırıyor. Böylece komisyon vermeden kart kırdırmış oluyorum."

G2: "Hocam bahis sitelerinin hoş geldin promosyon ödülleri var. $\mathrm{Bu}$ promosyon ödüllerini almak için Bitcoin (sanal para) almaları gerekiyor. Bunun için öğrencilerin hesap numaralarını kullanıyorlar. Ağlarına düşürdüklerin öğrencilere "bankadan hesap aç! Bankaya bizim telefon numaramızı ver!” diyor. Onay SMS'i aldıktan sonra işlemlerini yapıyorlar. Gerekli işlemlerini yaptıktan sonra da kartın hesabını kapatıp sonlandırıyor. $\mathrm{Bu}$ şekilde öğrencileri kullanıyor.

Benim bir arkadaşım aracı olmuştu. Ben de kartımı çıkardım ve tam kartımı aldım onlara verecektim ki aracı aradı benim kartımın hemen iptal edilmesini istedi. Sanırım birkaç kişi şikâyette bulunmuş"

G3: "Geçen sene yaz tatilinde birileri Ziraat Bankası'ndan hesap açıp kart çıkarmamızı istedi. Bu adamlar hesabımıza önce yüklü miktarda para aktaracaktı sonra da parayı çekecekti ve hesabımızı kapatacaktı. Kartlarımızın ve mobil uygulamalarımızın şifrelerini de istiyorlardı. Biz "neden böyle bir şeye ihtiyaç duyuyorsunuz?" diye sorduğumuzda bize 'ilk hesap açanlara hoş geldin faizi adı altında yüklü bir faiz verildiğini bunun için faize para yatırıp tekrar çektiklerini söylediler. 300 bin TL yatırıp 18-20 TL civarında faiz aldıklarını söylediler. Bunların işlerini organize eden komisyoncular var. Bu komisyoncular, öğrenicileri buluyor. Hesap açtıran herkese 50-100 TL arası bir para veriyor. Bu komisyoncunun Bursa da bir adamla çalıştığı söylendi. Öğrencilerin bir kısmı bu parayı almak için hesap açtırıyor."

G4: "Yani başka kırdırma yöntemleri var. Örneğin büyük teknoloji firmaları taksitle telefon ya da teknolojik cihazları taksitle satıyorlar. Öğrenciler de bu mağazalardan taksitle telefon alıyor. Faiziyle beraber 5 bin TL'ye aldıkları cihazları hiç kutusunu açmadan götürüp yerel telefonculara 4000 TL'ye sat1yor. Böylece nakit elde etmiş oluyor."
Nakde ihtiyaç duyma durumunda legal ya da daha rasyonel yöntemlerle ihtiyaçlarını karşılama durumunda olmayan bireylerin, bazı kart kırdırma dışında başka illegal yöntemlere başvurdukları gözlenmiştir. Bunlar; bazı suç organizasyonlarına banka hesabı sağlayarak gelir elde etme, kart kırdırma için sanal alışveriş sitelerini aracı olarak kullanma ve yine sanal alışveriş sitelerinden taksitle aldığ elektronik ürünü daha düşük fiyata küçük mağazalara satarak nakit elde etme yöntemlerini kullanmaktadırlar.

Ayrıca bazı öğrencilerin akraba arkadaşlarından borç istemek yerine neden kart kırdırdığına yönelik nitel görüşme verileri elde edilmiştir.

G2: "Limiti varsa yaparım. Kimseye ağız eğmemek için. Çünkü birinden borç aldığınızda, herhangi bir şeyde, akla borcu getiriyorlar. İnsana eyvallah çektiriyorlar. Bir minnet duymamak için bankaya paşa paşa öderim. Ben vermesem bile aileme kâğıt gider onlar öder [bankaya] borcumu! Bu yüzden karta başvuruyorum."

Yapılan görüşmelerde neredeyse görüşmecilerin tamamı Görüşmeci 2 ile benzer cevaplar vermişlerdir. Bir başkasına minnet duymamak, arkadaş ve akrabalarıyla iletişimlerini ve ilişkilerini olumsuz etkiyecek bir duruma mahal vermemek adına kimseden yardım istemediklerini dile getirmişlerdir.

Tablo 7: Kart Kırdırmanın Suç Olduğundan Haberdar Olmaları Durumları İle Ceza Almalarına Halinde Eylemi Tekrar Etme Eğilimleri Arasındaki İlişkiyi Gösteren Ki-Kare Testi Sonuçları

Ceza almaları halinde de eylemi

Kart Kırdırmanın gerçekleştirme durumu

Suç olduğunu bilme Evet, baska çarem

\begin{tabular}{llcccc} 
durumu & & \multicolumn{2}{c}{ kalmazsa yine yaparım } & Hayır yapmam & Toplam \\
\hline Evet & $\mathrm{F}$ & 17 & 5 & 22 \\
& $\%$ & 77,3 & 22,7 & 100,0 \\
Hayır & $\mathrm{F}$ & 58 & 52 & 110 \\
& $\%$ & 52,7 & 47,3 & 100,0 \\
\multirow{2}{*}{ Toplam } & $\mathrm{F}$ & 75 & 57 & 132 \\
& $\%$ & 56,8 & 43,2 & 100,0 \\
\hline Chi-Square Tests & Value & df & Asy. Sig. (2-sided) \\
Pearson Chi-Square & $4,502^{\text {a }}$ & 1 &, 034 & \\
\hline Fisher's Exact Test & Exact Significance (2-sided),037
\end{tabular}

Fisher's Exact Test Exact Significance (2-sided),037

Önce öğrencilerin kart kırdırma eyleminin bir suç olduğunu bilip bilmedikleri değişkeni, sonrasında da eylemi gerçekleştirirken ceza alabileceklerini bilmeleri halinde eylemi tekrarlayıp tekrarlamayacakları değişkeni sorgulanmıştır. Ayrıca iki değişken arasında da bir ilişkinin

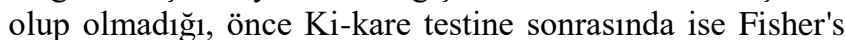
Exact ${ }^{1}$ testine tabi tutularak anlaşılmaya çalışılmıştır. Tablo 7'ye bakıldığında ceza alacağını bilmesi halinde bile eylemi tekrar edebileceğini belirtenlerin oranı yüzde 56,8 iken, hiçbir şartta tekrarlamayacağını söyleyenlerin oranı \% 43,2 olmuştur. Ancak eylemin suç olduğunu bilenlerin \% 77,3'ü kart kırdırma eylemini tekrarlayabileceğini, \% 22,7 ise tekrarlamayacağını ifade etmiştir. Burada anlaşılan, eylemin suç olduğunu bilenlerin büyük bir bölümünün,

1 Serbestlik derecesi (df)'nin 1 olduğu tablolarda hücrelerdeki değerlerin 1 tanesi dahi 5 'in altında olması durumunda Fisher's Exact Test uygulanması gerekmektedir (Can, 2017: 346). Hücrelerden hiçbiri 5'in altında olmamakla birlikte bir hücrenin 5 olması nedeniyle Fisher's Exact Testi de uygulanmıştır. 
ceza alabilme riskini çok önceden göze aldığıdır. Çarpıcı olan bir başka sonuç ise eylemin suç olduğunu bilmeyen öğrencilerin yarıya yakını $(\% 47,3)$ ceza alma riski hâsıl olduğunda da eylemi tekrarlayabileceklerini söylemelerdir.

Öğrencilerin kart kırdırma eyleminin suç olduğunu bilme durumları ile ceza alabileceklerini bilmeleri halinde eylemlerini tekrar etme durumları arasında Ki-kare testi $\left[\mathrm{X}^{2}\right.$ $(\mathrm{df}=1, \mathrm{n}=132)=4,5 ; \mathrm{P}<.05]$ ve Fisher's Exact testi $[(\mathrm{df}=1$, $\mathrm{n}=132) ; \mathrm{P}<.05]$ sonuçlarına göre anlamlı bir ilişki vardır.

\section{Hipotez 7: Doğrulanmıştır.}

Kart kırdırmanın suç olduğunu bilen öğrencilerin eylemlerini tekrar etmeleri ve bilmeyen öğrencilerin yarıya yakının ise ceza alma risklerinin olması halinde de eylemlerini tekrar ettireceklerini ifade etmeleri de hipotezi doğrulamaktadır.

Suç olduğu bildiği halde eylemi tekrar edeceğini ifade eden katılımcıların bu tutumlarının nedeni sorgulanmıştır. Buna yönelik görüşlerini yansıtan nitel görüşme verilerine aşağıda yer verilmiştir.

G1: "Evet, onların bu suçlarına belki ortak oluyoruz, ama bence bu suç değil! Yanlış yapıyor gibi görünüyor, ama yanlış değil bence. Marketlerden sadece sigara almak istediğinizde kartla alamıyorsunuz. Yanında bir sakız gibi küçük bir şey aldığınızda veriyorlar. Yani bu da mı suç? Bence kafede bir çay içmiş gibi, bir kahve içmiş gibi değerlendiriyorum."

G2: "Bunun cezas1 olduğunu düşünüyorum. Bunu yaptıran suçlu, yapan değil! Bunun için zaten bana ulaşamayacaklarını da biliyorum. Çünkü kafe işletmecisi de kendince önlem alıyor. Mesela yüklü çekimlerde kendi pos cihazını kullanmıyor. İnşaat firmaları gibi yüklü paranın akışının olduğu poslar kullanıyorlar. Hatta pos cihazı kiralıyorlar."

G10: "Evet ilk duyduğumda belki korkardım. Başka çıkış yolları arardım. Ama başka bir yol bulamazsam sanırım mecburen yine yapardım.

Bir ara çok sıkıntıdaydım. Çevrede bu durumu bilenler vardı. $\mathrm{Bu}$ yüzden bana iş karşılığında para teklifinde bulunanlar oldu. Bu teklif adam vurma teklifiydi. Arkadaş beni aradı "işte benim birinde 20 bin TL param var. Ayağına sıkacaksın paramı alacaksın sen de kendi payını alırsın dedi. Elbette 2500 lira gibi bir borcum için böyle bir şeyi yapamazdım. Sonra bir gün de bir ... iş konusu açtı. Bende hayırdır. İşçi mi lazım diye sordum. Aslında adam ağzımı aramak için lafı başta eveleyip geveliyordu. Sonra lafa girdi. Evet, işçi lazım dedi. Ben de ne iş yapacak ben yaparım dedim. $\mathrm{O}$ da bana elin silah tutuyor mu diye sordu. Ben biraz şaşırdım ve evet elim silah tutuyor dedim. Ben neden diye sorunca ilçelerde kumar oynatacaklarını söyledi. Eğer mağduriyetim biraz daha derin olsaydı. $\mathrm{Bu}$ yollarda gitme ihtimalim vard1."

Tefecilik eylemin kendisi suç olsa da bazı katılımcıların eylemin suç olmadığı, bazılarının ise cezai yaptırımın kendilerine yönelik olmayacağı kanaatinde olmaları nedeniyle suç eylemini tekrar etme tutumunu sergilemektedirler.
Tablo 8: Öğrencilerin Kart Kırdırma Sıklığı

\begin{tabular}{lcc}
\hline Zaman aralı̆̆ & Frekans & Yüzde \\
\hline Yılda bir kez & 37 & 28,0 \\
Yılda birkaç kez & 46 & 34,8 \\
Her ay & 49 & 37,1 \\
Toplam & 132 & 100,0 \\
\hline Chi-Square & \multicolumn{2}{c}{$1,773^{\mathrm{a}}$} \\
df & \multicolumn{2}{c}{2} \\
Asymptotic Significance & \multicolumn{2}{c}{, 412} \\
\hline
\end{tabular}

Kart kırdırma eylemini gerçekleştiren öğrencilerin eylemde bulunma sıklığı sorgulanmış, frekansların kategorilere dağılım Ki-kare testine tabi tutulmuş, $X^{2} \quad(d f=2$, $\mathrm{n}=132)=1,77 ; \quad \mathrm{P}>.05$ olarak tespit edilmiştir. Testin sonucunda dağılımlarda anlamlı bir farklılık olmadığ gözlenmiştir. Öğrencilerin kart kırdırma davranışı, zaman aralığına göre farklılık göstermemektedir. Bazı katılımcıların kart kırdırma sıklığına göre nitel görüşme verisi şöyledir:

G2: "Her ay neredeyse istisnasız yapıyorum. Geçen ay geç gittim kırdırmaya. Geçen ayın 7'sinde kartımı kırdıran esnaf beni aradı 'hayırdır bu ay gelmeyecek misin? Yoksa borçlarını hallettin mi?' diye sordu."

Bazı öğrenciler kart kırdırma eylemini düzenli olarak yapmaktadırlar. $\mathrm{Bu}$ durumun bazı esnaflarda düzenli müşteri algısı oluşturmuştur. Düzenli müşterisini kaybetmek ya da başkasına kaptırmak istemeyen bazı esnaflar, rutinin dışına çıkan öğrencilerle iletişime geçebilmektedir.

Tablo 9: Öğrencinin İlk Kez Kart Kırdırmasında Etkili Olan Faktör

\begin{tabular}{lcc}
\hline Faktör & Frekans & Yüzde \\
\hline Arkadaşlarımdan etkilendim. & 75 & 56,8 \\
Sosyal medyadan duydum & 2 & 1,5 \\
İnternet reklamında karşılaşım & 1 &, 8 \\
Akrabalarımdan öğrendim & 1 &, 8 \\
Çevremden duydum & 53 & 40,2 \\
Toplam & 132 & 100,0 \\
\hline Chi-Square & \multicolumn{3}{c}{$187,697^{\mathrm{a}}$} \\
df & \multicolumn{3}{c}{4} \\
Asymptotic Significance & \multicolumn{3}{c}{, 000} \\
\hline
\end{tabular}

Öğrencilerin kart kırdırma eylemini ilk kez gerçekleştirmesinde etkili olan faktörlerin dağılımında Kikare testi sonuçlarına [ $\left.\mathrm{X}^{2}(\mathrm{df}=4, \mathrm{n}=132)=187,6 ; \mathrm{P}<.05\right]$ göre anlamlı bir farklılık olduğu tespit edilmiştir. Öğrencilerin neredeyse tamamına yakını arkadaşlarından ve sosyal çevrelerinden etkilenerek kart kırdırma eylemini gerçekleştirmiştir.

Tablo 10: Çevresine ve Arkadaşlarına Kart Kırdırmayı Önerme Durumu

\begin{tabular}{lcc}
\hline Önerme durumu & Frekans & Yüzde \\
\hline Önerdim & 77 & 58,3 \\
Önermedim & 55 & 41,7 \\
Toplam & 132 & 100,0 \\
\hline
\end{tabular}

Öğrencilerin \% 58,3'i çevrelerine ve arkadaşlarına nakde ihtiyaç duymaları halinde kart kırdırmayı önerdiklerini ifade etmiştir. Kimseye herhangi bir öneride bulunmadıkları yönünde beyanda bulunanların oranı ise $\% 41,7$ olmuştur 
Hipotez 8: Tablo 9 ve Tablo 10'da yer alan veriler dikkate alında hipotezin doğrulandığı görülmektedir.

Bazı katılımcıların kart kırdırma eylemini arkadaşlarına önerme durumunu gösteren nitel görüşme verilerine aşağıda yer verilmiştir.

G2: "Ona [kart kırması için kuyumcuya] şimdiye kadar aşağı yukarı 8-9 kişi gönderdim yani! Birinden \% 5 komisyon alıyorsa ona müşteri sağladığım için benden $\% 3$ alıyor. Ona ismimle müşteri gönderiyorum. Gönderdiğim müşteriler için benden bazen kesinti de yapmadığı oluyor."

Yapılan görüşmelerde öğrencilerin büyük bir bölümü kart kırdırma eylemini, sorunlarının çözümünde yardımcı olma amacıyla arkadaşlarına önerdikleri anlaşılmıştır. Ancak bazı öğrencilerin bu durumu, bir gelir elde etme yöntemine dönüştürdüğü tespit edilmiştir.

Tablo 11: Öğrencinin Nakde İhtiyaç Duymasına Sebep Olan Giderler

\begin{tabular}{lcc}
\hline Giderler & Frekans & Yüzde \\
\hline Gida-giyim & 40 & 30,3 \\
Yurt-kira & 38 & 28,8 \\
Sigara & 5 & 3,8 \\
Kafe-eğlence & 3 & 2,3 \\
Kitap-kırtasiye & 3 & 2,3 \\
Ulaşım & 4 & 3,0 \\
Diğer & 39 & 29,5 \\
Toplam & 132 & 100,0 \\
\hline Chi-Square & \multicolumn{3}{c}{$113,212^{\mathrm{a}}$} \\
df & \multicolumn{3}{c}{6} \\
Asymptotic Significance & \multicolumn{3}{c}{, 000} \\
\hline
\end{tabular}

Öğrencilerin nakde ihtiyaç duymasında etkili olan giderlerin dağılımı Ki-kare testi sonuçlarına göre $\left[\mathrm{X}^{2}(\mathrm{df}=6\right.$, $\mathrm{n}=132$ ) $=113,2 ; \mathrm{P}<.05$ ] anlamlı bir farklılık sergilediği gözlenmiştir. Katılımcıların nakit para harcadığı başlıca gider kalemleri, gıda-giyim $(\% 30,3)$, yurt-kira $(\% 28,8)$ ve 'diğer' kategorisi içinde yer alan öngörülmeyen günlük ihtiyaçlardan $(\% 29,5)$ oluşmaktadır.

Tablo 12: Kart Kırdırma Eylemini Gerçekleștirdiği İş Yeri

\begin{tabular}{lcc}
\hline İşyerinin türü & Frekans & Yüzde \\
\hline Kuyumcu & 107 & 81,1 \\
Büfe-market & 12 & 9,1 \\
Ayakkabı mağazası & 3 & 2,3 \\
Telefon bayi & 1 &, 8 \\
İddia bayi & 1 &, 8 \\
Kafe & 1 &, 8 \\
Diğer & 7 & 5,3 \\
Toplam & 132 & 100,0 \\
\hline Chi-Square & \multicolumn{3}{c}{$486,015 \mathrm{a}$} \\
df & \multicolumn{3}{c}{6} \\
Asymptotic Significance & \multicolumn{3}{c}{, 000} \\
\hline
\end{tabular}

Kart kırdırma eyleminin, gerçekleştiği işyerine göre dağılımlarında Ki-kare testi sonucuna göre $\left[\mathrm{X}^{2} \quad(\mathrm{df}=6\right.$, $\mathrm{n}=132)=486,0 \quad \mathrm{P}<.05$ ] anlamlı bir farklılık olduğu tespit edilmiştir. Öğrenciler kart kırdırma işlemini yoğunlukla (\% 81,1) kuyumcularda gerçekleştirmektedir. Katılımcıların kart kırdırma eylemini gerçekleştirdikleri işyerleri ve bu işyerlerindeki işletmecilerin tutumlarına yönelik nitel görüşme verileri aşağıdaki gibidir.
G2: "Kuyumcular genelde yüksek komisyon alıyor. Giyimciler ve kafeler daha az komisyon aldıkları için ben onları tercih ediyorum. Bakkalı, giyimcisi, manavı, kafesi yani bunu yapan çok sayıda esnaf var, ama yoğunluklu olarak yapanlar kuyumculardır."

G3: “Arkadaşımla kuyumcuya gittik. Oradan önce bir çeyrek altın verdi bize, sonra biz altına elimizi sürdükten sonra tekrar masasına biraktık. Adam tekrar altını alıp yerine koyduktan sonra bize nakit parayı verdi. Yani bunu dini kaygılarını gidermek için yaptı herhalde, yani hülle gibi bir şey oldu. Sakallı biriydi. Hocalara benziyordu. Altının alış ile satış fiyatı arasında 12-13 TL filan oynuyordu. Ancak adam bizden 44 TL komisyon kesti. Altını alıp başka bir kuyumcuya gittiğimizde, kasada para yok, para çıkışı yapamam diyor. Yani altın satın alamayacağını söylüyor. Aslında onların yaptığı karşılıklı bir şey! Diğer kuyumcu görüyor ondan satın aldığımızı, o yüzden almıyor. Biz de altını satabileceğimiz başka kuyumcu arama riskine girmemek için mecburen kuyumcuya komisyon vermek zorunda kaliyoruz."

G4: "Evet çevremde çok yaygındır. Bu sadece Bingöl'de değil her yerde böyle Örneğin memleketimde (Malatya'da) sırf bunun için 10 tane çeyrek altın ve bir pos makinesi ile kuyumculuk yapıp bu işten kazanç sağlayanlar var. Yani aslında kuyumcu değil, çünkü dükkânın bilezik ya da diğer takılar yok sadece birkaç çeyrek altın ve pos cihazı var ve öğrencilerde sık sık oraya gider. Bingöl'de bu şekilde değil tabii, ama bu işten çıkar sağlayan kuyumcular ve başka esnaflar var."

G5: "Bazen giyim mağazasında yapıyorum. Bazen de kuyumcuda yapıyorum. Tabi kuyumcular bazen sıkıntı çıkarabiliyor. Yasak filan galiba! Çünkü kuyumcu kameranın karşısına geçip çeyreği veriyor, kamera için kör olan bir noktaya geçip çeyreği alıp nakdi veriyor. Sanırım şikâyetlerden filan çekiniyorlar."

Yukarıdaki ifadelerden kart kırdırma eyleminin birçok esnafta yapıldığı ama daha çok kuyumcular tarafindan yapıldığı anlaşılmaktadır. Kuyumcuların ise eylemi legal göstermek, dinen kendini tatmin etmek ya da eylemini yasal çerçevede meşru kılmak için çeşitli taktikler geliştirdikleri görülmektedir.

Ayrıca bazı çıkar çevrelerinin bunu bir rant kapısına dönüştürdüğü ve kuyumcu görünümünde tefecilik bürolarında hizmet verdikleri ileri sürülmüştür.

Tablo 13: Öğrencilerin, Kart Kırdırılmasına İmkân Tanıyan Esnafların Bir Tefecilik Faaliyeti Yürüttüklerini Bilme Durumları

\begin{tabular}{lcc}
\hline Bilme durumu & Frekans & Yüzde \\
\hline Evet, biliyorum & 76 & 57,6 \\
Hayır, bilmiyordum & 56 & 42,4 \\
Toplam & 132 & 100,0 \\
\hline Chi-Square & \multicolumn{2}{c}{$3,030^{\mathrm{a}}$} \\
df & \multicolumn{2}{c}{1} \\
Asymptotic Significance & \multicolumn{2}{c}{, 082} \\
\hline
\end{tabular}

Öğrencilerin kart kırdırma eyleminin gerçekleşmesine imkân tanıyan esnafin bir tür tefecilik yaptığını bilme durumlarının dağılımlarında Ki-kare testi sonuçlarına göre $\left[\mathrm{X}^{2} \quad(\mathrm{df}=1, \mathrm{n}=132)=3,03 ; \mathrm{P}>.05\right]$ anlaml 1 bir farklılık olmadığı tespit edilmiştir. Burada öğrencilerin kart kırdırma işleminde bulunmasında, işlemin bir tür tefecilik olduğunu bilip bilmemelerinin bir etkisi olmadığı anlaşılmaktadır. Bu 
tablonun verileri, Tablo 7 ile paralellik göstermekte ve Hipotez 7'nin doğrulanmasına katkı sağlamaktadır.

Tablo 14: Öğrencilerin Kendilerini Kart Kırdırma Bağımlısı Hissetme Durumları

\begin{tabular}{|c|c|c|}
\hline Bağımlılık hissi & Frekans & Yüzde \\
\hline Evet, bağımlıyım & 18 & 13,6 \\
\hline Hayır, bağımlı değilim & 91 & 68,9 \\
\hline Emin değilim & 23 & 17,4 \\
\hline Toplam & 132 & 100,0 \\
\hline $\begin{array}{l}\text { Chi-Square } \\
\text { df }\end{array}$ & & \\
\hline
\end{tabular}

Kart kırdırma eyleminin öğrencilerde bir bağımlılık hissi yaratıp yaratmadığına göre dağılımlarında Ki-kare testi sonucuna göre $\left[\mathrm{X}^{2}(\mathrm{df}=2, \mathrm{n}=132)=75,59 ; \mathrm{P}<.05\right]$ anlamlı bir farklılık olduğu gözlemlenmektedir. Bağımlı olmadıklarını düşünen öğrencilerin oranı \% 68,9 olurken, bağımlı olduklarını ifade edenlerin oranı \% 13,6 olarak gerçeklemiştir. Emin olmadığını ifade edenlerin oranı ise \% 17,4 olarak görülmektedir. Ancak bağımlı olmadığından emin olmama, bağımlı olduğu şüphesi duyma anlamına gelmektedir ki bunlara da bağımlı olduğunu düşünenler kategorisinde yer verilebilir. Bazı katılımcıların kendilerini bağımlı gibi hissetme durumlarına ilişkin nitel görüşme verileri aşağıdaki gibidir.

G2: "Çevremde kart kırdıran baya kişi var yani. Bu tam olarak bir bağımlılık olarak düşünmüyorum. Öğrenci hayatının zorluklarını bilirsiniz. Mecbur bırakıldıkça kirdirıyorum."

G6: "Yazın aslında kapatmak için elime para geçti. Ama geldiği gibi gitti. Aslında kapatma gereği duymadım. Alıştım kırdırmaya bana artık normal gibi geliyor."

Yukarıdaki ifadelerden anlaşılacağı üzere bazı öğrenciler kart kırdırma eyleminin bir bağımlılık değil bir zorunluluk olduğunu yönünde görüş bildirmiştir. Ancak Görüşmeci 6'nın ise firsatı olduğu halde kart borcunu kapatmayı tercih etmeyip kart kırdırmaya devam etmesi ve bunun kendisinde bir alışkanlığa dönüştüğünü ifade etmesi kart kırdırma eyleminin bağımlılık yaratabileceğinin belirtisi niteliğindedir.

\section{Tartışma ve Sonuç}

Emniyet Genel Müdürlüğü (EGM) 2017 yılı faaliyet raporuna göre Türkiye genelinde tefecilik, gittikçe yaygınlık kazanmaktadır. Rapora göre, hakkında işlem başlatılan tefecilik faaliyeti sayısı, yoğunluğun olduğu ilk on şehirde 298 olmuştur. Tefecilik işlemlerinde en büyük hacmi ise pos tefecilik oluşturmaktadır. Ancak bu rakam, sadece güvenlik güçlerince tespit edilen tefecilerin sayısını göstermektedir. 2018 yılı rakamlarına, 18 yaş üstü nüfusun 58 milyon civarında olduğu (TUIK, 2018) ayrıca banka ve kredi kartı ile yapılan nakit çekme ve alışveriş işlemi toplam sayısının 3 milyar 891 milyon 455 bin 369 olduğu (BKM, 2019) dikkate alındığında 18 yaş üstü olan birey başına düşen kart işlemi sayısının 67 olduğu görülmektedir. $\mathrm{Bu}$ rakamların büyüklüğü dikkate alındığında suiistimallerin de kart kullanma oranlarına paralel olarak arttığı, kayıt altında alınandan çok daha fazla suiistimalin olabileceği düşünülmektedir. Elbette bu suiistimali tetikleyen bazı unsurlar vardır. Bunlardan bazıları; tefecilik yapanların tahsilatlarını peşin yapıyor olması, tefecilerin uyguladığ 1 faizin bankalarındakinden daha uygun olması, altın ve telefon kontörü gibi bazı alanlarda katma değer vergisinden muaf olunması dolayısıyla da faturalandırmanın kolay olmasıdır (EGM, 2019).

Pos tefecilerden para alanlar, kredi kartı sahipleridir. Kart sahipleri, bazen zaruri ihtiyaçlardan kaynaklansa da, daha çok kontrolsüz tüketim alışkanlıklarından dolayı böyle bir olayın öznesi olabilmektedirler. Nitekim Türkiye'de ve dünyada yapılan bazı çalışmalar da bu savı destekler niteliktedir. Örneğin, Durukan vd. (2005) yaptığı çalışmada tüketici alışkanlıklarını etkileyen faktörlerin en başında \% 22,6 oranla kredi kartı ile taksitli alışveriş gelmektedir. Yani neredeyse her dört kişiden biri ileriye dönük borçlanabilmek için kredi kartı kullanmaktadır. Yine aynı çalışmada, tüketicilerin \% 51,4'ünün alışverişinde taksit, reklam ve promosyonların da bir miktar etkisinin olduğu ifade edilmiştir. Yurtdışında yapılmış araştırmalarda da benzer sonuçlara rastlanmıştır. Örneğin Amerika'da kadınların tüketim alışkanlıkları üzerine yapılan bir araştırmada ihtiyaçlarını karşılayamayacak düzeyde olan insanların kredi kartı ile alışverişleri, kartların cazip firsatlar sunması ile artmaktadır. Ancak, bu tüketicilerin önemli bir çoğunluğu ödeyemeyecekleri alışverişler yaparak zor duruma düşmektedir (Littwin, 2007). Achtziger vd. (2015) Almanya'da yaptıkları çalışmada borçlanma ile öz kontrol sevileri arasında ciddi bir ilişki olduğunu tespit etmiş̧lerdir. Sadece öz kontrol seviyeleri çok yüksek olanların alışverişlerinin zorunlu ihtiyaçlarıyla sınırlı kaldığını söylemektedir. Yani öz kontrol seviyesi çok güçlü olmayanlar, firsat oluşması halinde zaruri olmayan nedenlerde de borçlanabilmektedir.

Orta yaş ve orta yaş üstünde olanların yaşlarından ötürü deneyime sahip oldukları düşünüldüğünde öz kontrol sevilerinin daha yüksek olabileceği öngörülmektedir. Ancak, gençlerin kart kullanma alışkanlıkları daha kontrolsüz olabilmektedir. Hayhoe vd. (1999) Amerika'da üniversite öğrencileri üzerine yaptığı bir araştırmada kredi kartına sahip olma durumu ile harcama tutumu arasındaki ilişkiyi incelemiştir. Sahip oldukları kredi kartı arttıkça öğrencilerin harcama tutumlarının da güçlendiğini tespit etmiştir. Benzer bir sonuç Beale ve Jude'un (2017) çalışmasında da ortaya çıkmıştır. Öğrencilerin, borç etme imkânına sahip oldukça daha fazla harcama yaptıkları anlaşılmaktadır. Amerikadaki öğrenciler üzerine yapılan başka bir araştırmada Warwick ve Mansfield, (2000), öğrencilerin \% 71'nin kredi kartlarına ne kadar faiz ödediklerini bilmediği tespitinde bulunmuştur. Burada Amerikalı öğrencilerin borçlanırken, ne kadar faiz ödemeleri gerektiğine dikkat etmeyecek kadar kontrolsüz harcama yaptıkları anlaşılmaktadır. Warwick ve Mansfield, Amerika'daki dört yıllık birimlere kayıtlı olan üniversite öğrencilerinin yıllık toplam harcamalarının 30 milyar dolar, olduğunu, bunun 23 milyar dolarının harç, barınma, beslenme ve eğitim materyalleri için, 7 milyar dolarının ise 'pizza' parası olarak kullanıldığını ifade etmiştir. Burada pizzayı bir beslenme materyali olarak değil, bir sosyalleşme nesnesi olarak görmek daha doğru olacaktır.

$\mathrm{Bu}$ çalışmada ise nakit avans ve alışveriş kredisi tanımlanmış banka kartına sahip olan bazı öğrencilerin (\% 28,7) sahip oldukları legal ve illegal tüm borçlanma imkânlarını kullandıkları görülmüştür. Kalan öğrencilerin yani illegal borçlanmaya gitmemiş öğrencilerin yüzde 73,9'u da kartın sağladığı nakit borç imkânlarının tamamını 
kullandıkları anlaşılmaktadır. Ancak bu çalışmada elde edilen veriler ile Hayhoe ve diğerlerinin yaptı̆̆ çalışmada elde edilen veriler arasında bir noktada daha benzerlik vardır. Öğrenciler, ailelerinden ve arkadaşlarından borç almayı tercih etmemektedirler. Üniversite öğrencilerinin ailelerinden ilk defa uzak kalmaları, ailelerinin denetim ve kontrolünden çıkmaları ile bir boşluğa düştükleri anlaşılmaktadır. Boşluğa düşen öğrenciler, zorunlu ihtiyaçlarının yanında eğlence harcamaları ile limitlerini aşabilmektedirler. Bu durumu da ailelerine bildirmekten çekinen öğrenciler, sorunlarına çözüm bulmak amacı ile illegal bazı davranışlara yönelebilmektedirler. Jeffery, Burgess ve Akers'in öğrenme yaklaşımlarına göre bu durumun nedeni, istenmeyen davranışın (sapma davranışının) artışını engelleyen olumsuz pekiştirecin (ailenin sıkı kontrolünün ve azarlamasının) ortadan kalkmış olmasıdır (Akers vd., 1979; Burgess \& Akers, 1966; Jeffery, 1965).

Katılımcıların sorunlarına çözüm olarak en sık başvurdukları illegal çözüm yöntemi kart kırdırma olsa da başka çözüm yolları da geliştirmişlerdir. Örneğin, büyük sanal alışveriş firmalarını suistimal etmek ya da taksitle alınan bir ürünü daha ucuza nakit fiyata satarak gelir elde etmek. Ancak çözüm arayışında olan katılımcıların zaafları, bazı çevrelerce suistimal edilebilmektedir. Bu suistimaller arasında öğrencilerin, banka hesaplarını bahis çetelerine kullandırması gibi mala yönelik suçlar, hatta adam yaralamaya ya da cinayete azmettirilme gibi cana yönelik suçlar yer almaktadır.

Katılımcıların arasında kart kırdırma eyleminin suç olduğunu bilmeyenlerin dolayısıyla da ceza almayacaklarını düşündükleri daha basit illegal davranışlarda bulunanların oranının (\% 83,3) çok yüksek olduğu, ceza alma olasılıkları yüksek olan davranışları gerçekleştirenlerin oranının ise \% 1 ile 2 civarında olduğu anlaşılmaktadır. Bu verilerden yola çıkarak öğrenme kuramında 'olumlu ceza' olarak nitelendirilen uyarıcının (Akers vd., 1979; Burgess \& Akers, 1966; Jeffery, 1965), bireylerde sapma davranışının önlenmesinde büyük oranda etkili olduğu sonucuna ulaşılmaktadır.

$\mathrm{Bu}$ çalışmada, öğrenme yaklaşımında ileri sürülen teorilerle aynı anda hem çelişen hem de uyuşan verilere de ulaşılmıştır. Örneğin, kart kırdırmanın suç olduğunu bilenler arasında ceza alacağını bilmesi halinde bile eylemi tekrarlayacağını ifade edenlerin oranı \% 77,3 olarak tespit edilirken, suç olduğunu bilmeyenler arasında ise ceza alması halinde eylemi tekrarlayacağını belirtenlerin oranı $\%$ 52,7 çıkmıştır. Bu verilere bakıldığında eylemin suç olduğunu bilmeyenlerin ceza alacağını bilmeleri halinde eylemi tekrarlayacağını ifade edenlerin oranı neredeyse yarıya yakın oranında düşmüştür. Yani 'olumlu ceza', davranışın azalması konusunda doğru işlev görmüştür. Ancak suç olduğunu bilenler arasında bu oran dörtte biri dahi bulmamıştır. Yani her on bireyden yaklaşık sekizi, eylemi, ceza alacağını bilmesi halinde bile tekrar edeceğini ifade etmiştir ki, bu durum olumlu cezanın, bilinçli olarak gerçekleştirilen sapma davranışlarında pek de işlevsel olmadığını göstermiştir.

$\mathrm{Bu}$ çalışmada elde edilen en önemli sonuçlardan biri sapma davranışının öğrenme yoluyla yaygınlaştı̆̆ıdır. Katılımcıların toplamda \% 97'si ilk kez kart kırdırma eylemini gerçekleştirmesinde etkili olan faktörün arkadaşları ve çevresindekiler olduğunu belirtmiştir. Keskin ve Koparan, (2010) öğrenciler arasındaki iletişimin güçlenmesi ile kart kulanım alışkanlıkları arasında bir ilişkinin olabileceğini ifade etmişlerdir. $\mathrm{Bu}$ veriler Tarde'nin (1903) taklit kuramı destekler niteliktedir. Tarde, sosyal davranışların taklit yoluyla öğrenildiğini vurgulamaktadır. Bu çalışmada elde edilen nicel ve nitel verilerde de öğrencilerin, kart kırdırmayı arkadaşlarından öğrendiği, bu davranışı gerçekleştiren arkadaşlarına özenerek eylemde bulunduğu anlaşılmaktadır. Ayrıca Sutherland ve Akers de bireylerin yaşamlarında önem atfettikleri gruplarla iletişime geçerek hangi davranışın iyi yada kötü olduğunu öğrendiğini ifade etmekte, öğrenilen bu davranışın ve tutumun pekiştireçler ve cezalarla güçlendirildiğine dikkat çekmektedir (Akers vd., 1979; Burgess \& Akers, 1966; Metsueda, 2010). Bu çalışmadaki katılımcıların davranışlarının pekişmesi ve diğer bireylere yayılması Tarde'nin ve Akers'in yaklaşımları ile açıklanabilir. Çünkü bireyler, eylemin suç olduğunu bilmediğinden, eylemi gerçekleştirmekte hatta birbirilerine önermektedir. 'Olumlu ceza' uyarıcısının olmayışı yani bireylerin suçlarından dolayı cezalandırılmayışı, eylemin topluluk içinde artmasına neden olmaktadır. Ayrıca, yapılan gözlemlerden, öğrenmenin; Suhterland ve Akers'in de ifade ettikleri gibi yaşamlarında önem atfettikleri gruplarda yani aynı arkadaş grubu içindeki bireylerde arttığı anlaşılmıştır.

\section{Kaynakça}

Achtziger, A., Hubert, M., Kenning, P., Raab, G., \& Reisch, L. (2015). Debt Out Of Control: The Links Between Self-Control, Compulsive Buying, And Real Debts. Journal of Economic Psychology(49), 141-149.

Akers, R. L., Krohn , M., Lanza-Kaduce, L., \& Radosevich, M. (1979). Social Learnin And Deviant Behavior: A Spacific Test Of A General Theory. American Sociolocigal Review, 44(August), 636-655.

Arslan, Ç. (2014). Tefecilik Suçu. Ankara Barosu Dergisi(1), 23-47.

Bahar, K. (tarih yok). Ödünç Para Verme (İkrazatçılık ,Tefecilik ve Pos Tefecilik) İslemleri Ve Vergilendirilmesi. Ordu : SMMM Odası Yayınları.

Beale, E. M., \& Jude, B. (2017). College Students' Attitudes toward Debt. International Journal of Undergraduate Research and Creative, 9(5), 1-10.

Bekar, E. (2013). Tefecilik Suçu. İstanbul Üniversiesi Hukuk Fakültesi Mecmuası, 71(2), 499-526.

Bilge, B. (2015). Gelişen Teknolojinin Doğurduğu Yeni Bir Suç Türü: Kredi Kartı (POS) Tefeciliği. İnönü Üniversitesi Hukuk Fakültesi Dergisi, 1(Özel Sayı), 481-520.

BKM. (2019). Yerli Banka Kartlarının Yurtİçi ve Yurtdışı Kullanımı. 10 18, 2019 tarihinde Bankalararası Kart Merkezi: https://bkm.com.tr/yerli-ve-yabanci-kredikartlarinin-yurt-ici-kullanimi/ adresinden alındı

Burgess, R. L., \& Akers, R. (1966). A Differential Association-Reinforcement Theory of Criminal Behavior. Social Problems, 14(2), 128-147. 
Bülent, B., Budak, G. S., \& Y1lmaz, H. (2012). Kredi Kartlarının Rasyonel Kullanımını Etkileyen Bireysel

Büyüköztürk, Ş. (2011). Sosyal Bilimler İçin Ístatistik. Ankara: PEGEM.

Büyüköztürk, Ş., Kılıç Çakmak, E., Akgün, Ö. E., Karadeniz, Ş., \& Demirel, F. (2018). Ĕ̈itimde Bilimsel Araştırma Yöntemleri. Ankara: Pegem Akadami.

Can, A. (2017). SPSS Ile Bilimsel Araştırma Sürecinde Nicel Veri Analizi. Ankara: Pegem Akademi.

Cenikli, S. (2017, 11 08). Kuyumcu Görünümlü Kredi Kartı Tefecileri. 09 19, 2019 tarihinde Hürriyet Gazetesi: http://www.hurriyet.com.tr/ekonomi/kuyumcugorunumlu-kredi-karti-tefecileri-40637889 adresinden alınd

Durukan, T., Elibol, H. , \& Özhavzal1, M. (2005). Kredi Kartlarındaki Taksit Uygulamasının Tüketicinin Harcama Alışkanlıkları Üzerindeki Etkisi. Selçuk Üniversitesi Sosyal Bilimler Enstitüsü Dergisi(13), 143-154.

EGM. (2019). Kaçakçılık ve Organize Suçlarla Mücadele 2017 Raporu. Emniyet Genel Müdürlüğü Kaçakçılık ve Organize Suçlarla Mücadele Daire Başkanlığı. Ankara: KOM Yayınları.

Girginer, N., Erken-Çelik, A., \& Uçkun , N. (2008). Eskisehir Osmangazi Üniversitesi Iktisadi ve Idari Bilimler Fakültesi Ögrencilerinin Kredi Kartı Kullanımlarına Yönelik Bir Arastırma. Anadolu Üniversitesi Sosyal Bilimler Dergisi, 8(1), 193-208.

Gönenç, İ. (2010). Tefecilik Suçu. Gazi Üniversitesi Hukuk Fakültesi Dergisi, 14(1), 543-553.

Gün, T. (2019). Türk Ceza Kanunu'nda Tefecilik Suçu. Türkiye Barolar Birliği Dergisi(141), 179-207.

Güntekin, H. (2014). Kredi Kartı Kullanılması Suretiyle Tefecilik Suçu. Bankacılar Dergisi, 25(88), 91-108.

Hayhoe, C. R., Leach, L., \& Turner, P. (1999). Discriminating The Number Of Credit Cards Held B y College Students Using Credit And Money Attitudes. Journal of Economic Psychology(20), 643-656.

Jeffery, C. R. (1965). Criminal Behavior and Learning Theory. The Journal of Criminal Law, Criminology and Police Science, 56(4), 294-300.
Faktörler. Eskişehir Osman Gazi Üniversitesi İ̈BF Dergisi, 7(2), 67*93.

Karakehya, H. (2013). Türkiye'de Giderek Artan Hukuka Aykırı Bir Ekonomik Faaliyet Olarak Kredi Kartı Kullanılması Suretiyle Tefecilik. International Conference on Eurasian Economies (s. 932-936). Sn Petersburg: Beyketn University. https://www.avekon.org/proceedings/avekon04.pdf adresinden alınd 1

Karasar, N. (2017). Bilimsel Araştırma Yöntemi: Kavramlar, Ilkeler, Teknikler. Anakra: Nobel Yayınlar1.

Keskin, H. D., \& Koparan, E. (2010). Üniversite Öğrencilerinin Kredi Kartı Sahipliğini Belirleyen Faktörler. Eskişehir Osmangazi Üniversitesi IIBBF Dergisi, 5(1), 111-129.

Littwin, A. (2007). Beyond Usury A study of Credit-Card Use And Preference Among low-income Consumers. Harvard Law School Faculty Scholarship Series. 11 13, $2019 \quad$ tarihinde https://papers.ssrn.com/sol3/papers.cfm?abstract_id= 968330 adresinden alınd 1

Metsueda, R. L. (2010). Sutherland, Edwin H.: Differential Association And Differential Social Organization. F. T. Cullen, \& P. Wilcox içinde, Encyclopedia of Criminological Theory (s. 898-906). Thousand Oaks, CA. USA: SAGE Publication.

Tarde, G. (1903). The Laws of Imitation. New York: Henry Hold and Company.

TCK. (2004, 09 26). 5237 Sayılı Türk Ceza Kanunu. 11 28, 2019 tarihinde https://www.mevzuat.gov.tr/MevzuatMetin/1.5.5237 .pdf adresinden alınd 1

TUİK. (2018). Nüfus İstatistikleri. 12 23, 2019 tarihinde Türkiye İstatistik Kurumu: http://www.tuik.gov.tr/UstMenu.do?metod=temelist adresinden alınd 1

Warwick, J., \& Mansfield, P. (2000). Credit Card Consumers: College Students' Knowledge And Attitude. Journal of Consumer Marketing, 17(7), 617-626.

Xiao, J. J., Noring, F. E., \& Anderson, J. G. (1995). College Students' Attitudes Towards Credit Cards. Journal of Consumer Studies and Home Economics, 155714. 
T.C.

BINGÖL ONIVERSITESI

(Bilimsel Araşurma ve Yayın Etik Kurul Başkanlı̌̆ı)

Karar No: 58

Sayın Dr.Öğr. Üyesi Mehmet Seyman ÖNDER

(Fen-Edebiyat Fakültesi)

Oniversitemiz Fen-Edebiyat Fakültesi Dr.Öğr. Ôyesi Mehmet Seyman ÖNDER tarafindan sunulan "Doḡubayazıt'ta Sınır Kaçakçı̆ğı Üzerine Sosyolojik Bir Araştırma" adlı çalışması, Türkiye'nin güney kentleri olan ve Suriyeli mültecilerin yoğunluklu yaşadığı Hatay, Şanlıurfa, Gaziantep, Mardin ve Diyarbakır'da bölge halkına yönelik olarak yapılacak olan "Suriyeli Mültecilere Vatandaşlık Verilmesine Etiketleme Kuramı Çerçevesinde Halkın Yaklaşımı" adhı çalıșması, Dört siyasi ana akımı temsilen dört siyasi partinin üyelerine yönelik yapılacak olan "Siyasi Parti Ôyelerinin Sosyal Sosyal Medya'yı Ideolojik Kullanımı ve Illlegal Propagandaya Yŏnelik Tutumları" adıı çalıșması, Doğu Anadolu'da Van Gölü Elektrik Dağı̆ım Şirketinin faaliyet alanı olan Van, Muş ve Bitlis ile Gunneydoğu'da Dicle Elektrik Dağıtım Şirketi faaliyet alanı olan Diyarbakır, Urfa ve Batman'da yapılan "Kaçak Elektrik Kullanımında Suçun Meşru Algılanması" adı çalışması ve Bingől Oniversitesi Öğrencilerine yönelik yapılan "Bingöl Öniversite Öğrencilerinin Ekonomik Problemlerinin Yarattığı Sorun: POS Tefecilik" isimli anket çalıșmalanı Kurulumuz tarafin̨dan etik yönden değerlendirilmiștir.

Değerlendirme sonucunda; sŏz konusu anket çalıșmasının Üniversitemiz Etik Kurul Yönergesi ilkeleri çerçevesinde değerlendirilmiş ve araştırma etiği açısından "UYGUN OLDUĞUNA" oy birliği ile karar verilmiștir. 26/12/2018

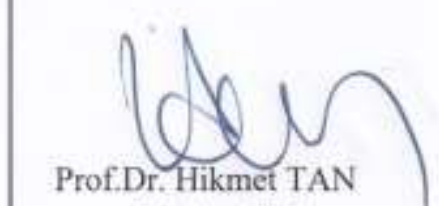

Başkan Yrd.

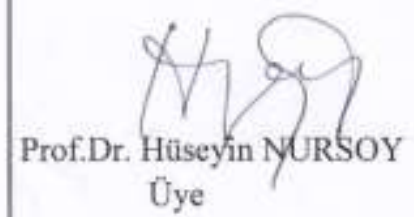

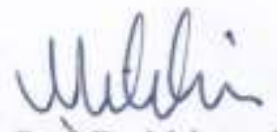

Prof. Dr. Mehmet çifTCi

Bașkan

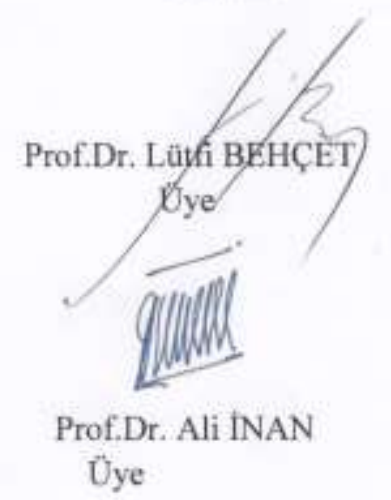

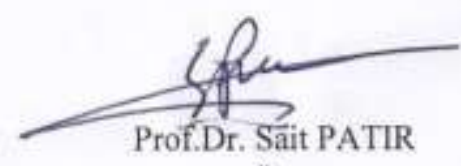

Oye

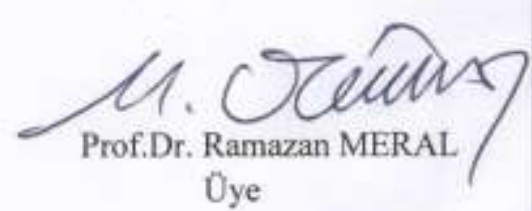

